\title{
PENGARUH PENYULUHAN KESEHATAN TERHADAP PERUBAHAN PENGETAHUAN DAN SIKAP MASYARAKAT PADA PENDERITA GANGGUAN JIWA
}

\author{
Uswatun Hasanah ${ }^{1}$ \\ ${ }^{1}$ Akper Dharma Wacana Metro \\ emailnyauus@gmail.com
}

\begin{abstract}
ABSTRAK
Gangguan jiwa merupakan salah satu masalah kesehatan masyarakat yang serius dan harus segera ditanggulangi. Masih adanya sikap masyarakat yang negatif serta memiliki pengetahuan yang rendah tentang gangguan jiwa perlu mendapatkan perhatian. Salah satu cara yang tepat untuk merubah sikap dan meningkatkan pengetahuan masyarakat adalah melalui penyuluhan kesehatan. Penelitian ini bertujuan untuk mengetahui pengaruh penyuluhan kesehatan terhadap perubahan tingkat pengetahuan dan sikap masyarakat pada penderita gangguan jiwa. Jenis penelitian ini menggunakan metode quasi experiment, bentuk desain yang dipakai adalah desain one group pre test-post test. Pengambilan sampel menggunakan teknik purposive sampling. Sampel dalam penelitian yang digunakan dalam penelitian ini akan diambil sebesar 10\% dari jumlah populasi yang ada yaitu sebanyak 47 orang. Instrumen penelitian menggunakan kuesioner, penyuluhan dengan media power point dan leaflet. Hasil uji normalitas didapatkan data berdistribusi normal sehingga untuk analisis data menggunakan uji paired sample $t$ test. Hasil analisis menunjukkan $p$ value 0,000. Hasil penelitian ini menunjukkan bahwa penyuluhan kesehatan dapat meningkatkan pengetahuan dan sikap masyarakat terhadap pasien gangguan jiwa.
\end{abstract}

Kata kunci: penyuluhan kesehatan, pengetahuan, sikap, gangguan jiwa.

\section{THE EFFECT OF HEALTH EDUCATION ON CHANGES IN COMMUNITY KNOWLEDGE AND ATTITUDES IN MENTAL DISORDERS}

\begin{abstract}
Mental disorder is a serious public health problem and must be addressed immediately. The existence of negative community attitudes and low knowledge about mental disorders needs attention. One of the right ways to change attitudes and improve people's knowledge is through health education. The aims of this study is to determine the effect of health education on changes in the level of knowledge and attitudes in people with mental disorders. This type of research uses the quasi experiment method, using one group pre-post test. The sample in the study used in this study will be taken at $10 \%$ of the total population. A number of 47 samples were recruited using purposive sampling technique. The research instrument used questionnaires, counseling with power point media and leaflets. The results of the normality test obtained normal distribution data so that for data analysis using paired sample $t$ test. The results of the analysis show $p$ value 0,000. The results of this study indicate that health education can improve people's knowledge and attitudes towards mental disorder patients.
\end{abstract}

Keywords: health education, knowledge, attitude, mental disorder

\section{PENDAHULUAN}

Gangguan mental adalah pola psikologis atau perilaku yang pada umumnya terkait dengan stress atau kelainan mental yang tidak dianggap sebagai bagian dari perkembangan normal manusia. Gangguan tersebut didefinisikan sebagai kombinasi afektif, perilaku, komponen kognitif atau persepsi, yang berhubungan dengan fungsi tertentu pada daerah otak atau sistem saraf yang menjalankan fungsi sosial manusia. Terjadinya gangguan jiwa disebabkan oleh karena ketidakmampuan manusia untuk mengatasi konflik dalam dirinya, tidak terpenuhi kebutuhan hidup, perasaan kurang diperhatikan, perasaan rendah diri sehingga perasaan kehilangan sesuatu yang berlebihan. Di samping itu juga banyak faktor yang 
mendukung timbulnya gangguan jiwa meliputi biologis, psikologis, sosial dan lingkungan (Nawawi, 2013).

World Health Organization (WHO) menyatakan bahwa masalah gangguan kesehatan jiwa di seluruh dunia sudah menjadi masalah yang sangat serius dan diperkirakan ada sekitar 450 juta orang di dunia yang mengalami gangguan kesehatan jiwa (Yosep \& Sutini, 2014). Angka kejadian gangguan jiwa di Indonesia juga cukup tinggi. Berdasarkan hasil Riset Kesehatan Dasar tahun 2013 jumlah penderita gangguan jiwa di Indonesia mencapai 1,7 per 1000 penduduk. Prevalensi tertinggi terjadi di Yogyakarta dan Aceh masing-masing 2,7\%, sedangkan terendah di Kalimantan Barat yaitu sebesar 0,7\%. Untuk Provinsi Lampung jumlah penderita gangguan jiwa didapatkan sebesar $0,8 \%$ (Badan penelitian \& Pengembangan Kesehatan Kementerian Kesehatan RI, 2013).

Gangguan jiwa merupakan salah satu masalah kesehatan masyarakat di Indonesia yang serius dan harus segera ditanggulangi. Sikap masyarakat terhadap penderita gangguan jiwa saat ini memang berbeda-beda. Sikap sendiri merupakan respons tertutup seseorang terhadap stimulus atau objek tertentu, yang sudah melibatkan faktor pendapat dan emosi yang bersangkutan (senang-tidak senang, setuju-tidak setuju, baik-tidak baik, dan sebagainya) (Notoatmodjo, 2010).

Pandangan masyarakat belakangan ini mengenai permasalahan penderita gangguan jiwa, selalu di identikkan dengan sebutan orang gila. Tanpa disadari secara tidak langsung hal ini merupakan sikap yang keliru dari kita sehingga orang memandang penderita gangguan sebagai suatu masalah yang negatif yang selalu mengancam, padahal gangguan jiwa merupakan suatu penyakit yang statusnya sama dengan penyakit-penyakit lain yang harus segera diobati dan disembuhkan.

Pengetahuan dan pemahaman yang minim tentang gangguan jiwa masih banyak dimiliki oleh masyarakat Indonesia. Ketidaktahuan mereka terhadap permasalahan kesehatan jiwa membuat masyarakat cenderung bertindak/bersikap spontan yang berefek negatif terhadap orang dengan gangguan jiwa (Yancen, 2015).

Masih adanya sikap masyarakat yang negatif serta memiliki pengetahuan yang rendah tentang gangguan jiwa perlu mendapatkan perhatian. Salah satu cara yang tepat untuk merubah sikap dan meningkatkan pengetahuan masyarakat adalah melalui penyuluhan kesehatan. Penyuluhan/ penyuluhan kesehatan pada hakikatnya adalah suatu kegiatan atau usaha menyampaikan pesan kesehatan kepada masyarakat, kelompok atau individu. Dengan harapan bahwa dengan adanya pesan tersebut, maka masyarakat, kelompok atau individu dapat memperoleh pengetahuan tentang kesehatan yang lebih baik. Pengetahuan tersebut pada akhirnya diharapkan dapat berpengaruh terhadap perilaku. Dengan kata lain dengan adanya penyuluhan kesehatan tersebut diharapkan dapat membawa akibat terhadap perubahan perilaku kesehatan dari sasaran (Notoatmodjo, 2010).

Penelitian yang dilakukan oleh Pratomo (2013) menunjukkan adanya pengaruh penyuluhan kesehatan terhadap perubahan tingkat pengetahuan dan sikap masyarakat pada gangguan jiwa di Desa Nguter, Kab. Sukoharjo. Penyuluhan kesehatan sangat dibutuhkan untuk meningkatkan pengetahuan masyarakat tentang kesehatan jiwa sehingga sikap masyarakat menjadi positif terhadap penderita gangguan jiwa.

\section{METODE}

Jenis penelitian ini menggunakan metode quasi experiment, bentuk desain yang dipakai adalah desain one group pretest-posttest. Pengambilan sampel menggunakan teknik purposive sampling. Sampel dalam penelitian yang digunakan dalam penelitian ini akan diambil sebesar $10 \%$ dari jumlah populasi yang ada yaitu sebanyak 47 orang di Wilayah kerja Puskesmas Mulyojati Kota Metro Lampung.

Instrumen penelitian menggunakan kuesioner, penyuluhan dengan media power point dan leaflet. Penelitian ini menggunakan alat ukur berupa kuesioner pengetahuan tentang kesehatan jiwa dan sikap pada penderita gangguan jiwa. Peneliti memodifikasi kuesioner dengan menyesuaikan karakteristik responden dan sesuai dengan tujuan penelitian. 
Kuesioner yang digunakan dalam penelitian ini menggunakan skala Likert yang dirancang oleh peneliti berdasarkan studi pustaka. Analisis bivariat menggunakan uji paired sample t test.

\section{HASIL}

Adapun hasil penelitian disajikan pada tabel berikut:

Tabel 1.

Usia Responden $(\mathrm{n}=47)$

\begin{tabular}{lcc}
\hline Usia & $\mathrm{f}$ & $\%$ \\
\hline $26-35$ & 18 & 38.29 \\
$36-45$ & 20 & 42.55 \\
$46-55$ & 6 & 12.76 \\
$56-65$ & 3 & 0.60 \\
\hline Distribusi usia responden terbanyak pada & yaitu rentang usia dewasa awal berjumlah 18 \\
rentang usia dewasa akhir yaitu sebanyak 20 & responden (38.29\%).
\end{tabular}

responden $(42.55 \%)$. Usia terbanyak ke dua

Tabel 2.

Pengetahuan responden tentang kesehatan jiwa $(n=47)$

\begin{tabular}{lcccc}
\hline Pengetahuan & \multicolumn{2}{c}{ Pre test } & \multicolumn{2}{c}{ Post test } \\
\cline { 2 - 5 } & $\mathrm{f}$ & $\%$ & $\mathrm{f}$ & $\%$ \\
\hline Baik & 3 & 6.4 & 18 & 38.3 \\
Cukup & 15 & 31.9 & 19 & 40.4 \\
Kurang & 29 & 61.7 & 10 & 21.3 \\
Berdasarkan tabel 2 diketahui pada pre test & 19 responden $(40.4 \%)$ & pada post test. \\
pengetahuan terdapat 3 responden $(6.4 \%)$ & \multicolumn{2}{l}{ Sedangkan responden dengan pengetahuan } \\
dengan pengetahuan baik dan post test menjadi & kurang terdapat 29 responden (61.7\%) turun \\
18 responden (38.3\%). Terdapat 15 responden & menjadi 10 responden (21.3\%) pada post test.
\end{tabular}

Tabel 3.

Sikap respoonden terhadap penderita gangguan jiwa $(\mathrm{n}=47)$

\begin{tabular}{lcccc}
\hline Sikap & \multicolumn{2}{c}{ Pre test } & \multicolumn{3}{c}{ Post test } \\
\cline { 2 - 6 } & $\mathrm{f}$ & $\%$ & $\mathrm{f}$ & $\%$ \\
\hline Positif & 21 & 44.7 & 35 & 74.5 \\
Negatif & 26 & 55.3 & 12 & 25.5 \\
\hline Tabel 3 diketahui terdapat 21 responden & mengalami penurunan dari 26 responden \\
(44.7\%) memiliki sikap positif pada pre test & \multicolumn{2}{c}{ (55.3\%) pada pre test menjadi 12 responden } \\
dan meningkat menjadi 35 responden (74.5\%) & (25.5\%) pada post test. &
\end{tabular}

Tabel 4.

Rata-Rata Pengetahuan Masyarakat Sebelum dan Sesudah Penyuluhan Kesehatan

\begin{tabular}{cccccc}
\hline Data & Mean & SD & SE & P Value & N \\
\hline Pre test Pengetahuan & 50.35 & 16.26 & 2.37 & \multirow{2}{*}{000} & \multirow{2}{*}{47} \\
Post test pengetahuan & 68.37 & 15.37 & 2.24 & & \\
\hline
\end{tabular}

Tabel 5.

Rata-rata sikap mayarakat sebelum dan sesudah penyuluhan kesehatan $(\mathrm{n}=47)$

\begin{tabular}{lcccc}
\hline \multicolumn{1}{c}{ Data } & Mean & SD & SE & P Value \\
\hline Pre test Sikap & 4.60 & 1.89 & 0.277 & \multirow{2}{*}{.000} \\
Post test Sikap & 6.85 & 1.64 & 0.239 & \\
\hline
\end{tabular}


Hasil uji statistik dengan menggunakan Paired samples $t$ test menunjukan, terdapat pengaruh penyuluhan kesehatan terhadap tingkat pengetahuan keluarga dan masyarakat, dengan Sig. (2-tailed) 0.000 dimana jika nilai probabilitas < 0.05 maka hipotesis atau $\mathrm{H} 0$ ditolak. Berdasarkan tabel 5 menunjukkan hasil sikap responden sebelum dilakukan penyuluhan kesehatan didapatkan nilai ratarata sebesar 4.60. Sedangkan untuk nilai ratarata setelah dilakukan penyuluhan kesehatan sebesar 6.85. Hasil uji statistik dengan menggunakan Paired samples $t$ test menunjukan, terdapat pengaruh penyuluhan kesehatan sikap keluarga dan masyarakat, dengan Sig. (2-tailed) 0.000 dimana jika nilai probabilitas $<0.05$ maka hipotesis atau $\mathrm{H} 0$ ditolak.

\section{PEMBAHASAN}

Hasil post test setelah dilakukan penyuluhan kesehatan didapatkan bahwa rata-rata pengetahuan responden meningkat menjadi baik yaitu 18 responden (38.3\%). Pada saat melakukan penyuluhan kesehatan peneliti menggunakan metode ceramah. Peneliti menyampaikan ceramah dengan baik sehingga mampu dimengerti oleh responden.

Terdapat keuntungan dari metode ceramah yaitu mudah disampaikan serta mampu dipahami dengan baik. Selain itu adanya komunikasi dua arah menyebabkan responden lebih memahami hal yang disampaikan oleh peneliti. Faktor yang mempengaruhi tingkat pengetahuan seseorang adalah informasi yang diterima oleh seseorang dengan sumber informasi yang didapatkan dari beberapa sumber yang salah satunya adalah dari penyuluhan kesehatan. Penelitian Wawan (2010) menyebutkan bahwa faktor yang dapat mempengaruhi pengetahuan seseorang berawal dari informasi yang diperoleh dan sumber informasi yang lebih banyak.

Selain menggunakan metode ceramah, peneliti menggunakan media presentasi power point dan leaflet. Menurut penelitian Daryanto (2013) bahwa pemilihan media presentasi dapat disajikan berupa teks, gambar serta animasi yang dikombinasikan. Sehingga penggunakan media presentasi ini mampu menarik perhatian dari responden dalam melaksanakan penyuluhan kesehatan sehingga dapat meningkatkan pengetahuan responden. Penelitian lain yang dilakukan oleh Liang dkk (2013), menyatakan bahwa penyuluhan kesehatan menggunakan metode ceramah dan media presentasi sangat efektif dalam meningkatkan pengetahuan responden (Notoatmodjo, 2010).

Penyuluhan kesehatan dengan media presentasi menampilkan slide gerak dan gambar sedangkan media leaflet menampilkan tulisan dan gambar secara langsung yang membuat terkesan formal. Pada saat penelitian responden sangat antusias dengan melihat media yang menarik. Penggunaan media diartikan sebagai perantara yang sering dijumpai dalam berbagai kegiatan seperti proses belajar mengajar, seminar, rapat dan kegiatan ceramah lainnya. Selain itu, media sebagai sumber pesan dengan penerima pesan atau informasi sehingga media dapat diartikan sebagai perantara atau penghubung antara dua pihak (Anita, 2010). Media pembelajaran mampu mempengaruhi efektifitas pembelajaran sehingga mampu meningkatkan peserta didik dalam belajar dan mampu membantu meningkatkan penyerapan materi dan memfokuskan informasi pengetahuan (Arsyad, 2006).

Penyuluhan kesehatan adalah proses untuk meningkatkan kemampuan masyarakat dalam memelihara dan meningkatkan kesehatan. Selain itu untuk mencapai derajat kesehatan yang sempurna baik fisik, mental dan sosial maka masyarakat harus mampu mengenal dan mewujudkan aspirasinya, kebutuhannya dan mampu mengubah atau mengatasi lingkungannya baik lingkungan fisik, sosial, budaya dan sebagainya (Notoatmodjo, 2010). Menurut Nondyawati (2015) terjadinya peningkatan pengetahuan setelah pemberian penyuluhan kesehatan menujukan adanya dampak positif sebagai upaya peningkatan derajat kesehatan. Pengaruh dari lingkungan memberikan dampak pada tingkat pengetahuan individu dimana orang sering menjumpai suatu hal yang sama akan lebih mudah untuk mengingat, pengetahuan individu atau kelompok dapat meningkat apabila sering menjumpai suatu hal yang baru sehingga dapat meningkatkan derajat kesehatan (Grassi, dkk 2014). Penelitian yang serupa menunjukkan tingkat pengetahuan keluarga dalam pemberian 
motivasi pada klien gangguan jiwa, terjadi perubahan setelah dilakukan penyuluhan kesehatan (Nondyawati, 2015).

Tingkat pengetahuan selanjutnya mempengaruhi sikap masyarakat kepada pasien gangguan jiwa. Sikap (attitude) merupakan reaksi atau respon seseorang yang masih tertutup terhadap stimulus atau obyek. Sikap menunjukkan konotasi adanya kesesuaian reaksi terhadap stimulus tertentu. Menurut Notoatmodjo (2010), sikap merupakan kesiapan atau kesediaan untuk bertindak dan bukan merupakan pelaksanaan motif tertentu. Sikap belum merupakan suatu tindakan atau aktivitas, akan tetapi merupakan predisposisi tindakan suatu perilaku.

Perbedaan sikap seseorang memberikan indikasi bahwa sikap positif akan memberikan kontribusi terhadap perilaku positif pada obyek yang dikenai perilaku tersebut. Dalam hal ini apabila seorang keluarga memiliki sikap menerima (bersedia memperhatikan stimulus) kemudian merespon terhadap apa yang diketahui tentang pentingnya memberikan dukungan, sehingga bila sikap positif secara terus menerus maka keluarga dengan motivasi dalam memberikan dukungan terhadap klien gangguan jiwa rendah bias menjadi sedang bahkan bisa menjadi tinggi. Dalam proses pembentukan sikap dipengaruhi oleh beberapa faktor yaitu pengalaman pribadi, pengaruh orang lain yang dianggap penting, pengaruh kebudayaan, media massa, lembaga penyuluhan dan lembaga agama dan pengaruh faktor emosional (Azwar, 2011).

Sikap seseorang dalam memberikan dukungan merupakan langkah awal dalam sebuah motivasi dalam memberikan dukungan terhadap klien gangguan jiwa terutama agar proses penyembuhannya berjalan dengan cepat, apabila sikap dalam dalam memberikan dukungan tidak baik, bias di pastikan motivasi dalam memberikan dukungan terhadap klien gangguan jiwa rendah, sikap dalam memberikan dukungan tersebut seperti dukungan informasi, dukungan harga diri, dan dukungan praktis harus di miliki keluaarga agar motivasi dalam memberikan dukungan terhadap klien gangguan jiwa tinggi (Utami dan Marlyn, 2004).
Sikap negatif adalah sikap tidak menyetujui, menolak atau tidak menyenangi (Saam \& Wahyuni, 2013). Sikap masih merupakan suatu kesiapan atau kesediaan untuk bertindak. Dengan kata lain, sikap belum merupakan tindakan atau aktivitas, namun merupakan suatu kecenderungan seseorang untuk bertindak terhadap suatu objek dilingkungan tertentu sebagai suatu penghayatan terhadap objek tersebut.

Hal ini didukung oleh penelitian yang dilakukan oleh Yulianti (2016), yang menyatakan ada hubungan antara tingkat penyuluhan dengan sikap masyarakat terhadap pasien gangguan jiwa. Salah satu proses yang berkontribusi dalam pembentukan sikap tersebut adalah penyuluhan, karena pada saat menjalani penyuluhan seseorang mempelajari sesuatu, mengetahui konsep-konsep tentang sebuah hal dan pada akhirnya pemahaman tersebut akan membentuk sikap seseorang terhadap sebuah objek atau sesuatu hal. Penelitian yang dilakukan oleh Wiharjo (2014) juga menyatakan bahwa terdapat faktor lain yang mempengaruhi sikap yaitu persepsi masyarakat, yaitu terdapat hubungan positif yang signifikan antara persepsi masyarakat dengan sikap masyarakat terhadap penderita skizofrenia. Perbedaan persepsi masyarakat terhadap penderita gangguan jiwa dipengaruhi oleh beberapa faktor, diantaranya kurangnya informasi mengenai penyakit ini, masih banyak masyarakat yang tidak mengetahui tentang gangguan jiwa.

Sikap merupakan bentuk respon seseorang terhadap objek tertentu, biasanya melibatkan beberapa faktor emosi dan argumen (Azwar, 2011). Meskipun sikap bukan merupakan suatu tindakan langsung melainkan tindakan predisposisi yang bisanya dapat dipengaruhi beberapa faktor terbentuknya sikap, yaitu orang yang dianggap penting (Wawan, 2010). Orang penting yang dimaksud adalah keluarga atau kerabat dan masyarakat yang berada dilingkungan sekitar. Perubahan sikap dari individu dapat dipengaruhi dari lingkungan sosial (Azwar, 2011). Peranan dari orangorang terdekat bisa memberikan dampak baik positif maupun negatif. Menurut Lacko dkk (2012), pandangan negatif masyarakat terhadap orang dengan gangguan jiwa dapat merusak individu dengan gangguan jiwa 
terdapat hubungan dengan beban sosial yang cukup besar.

Pemberian arahan dan sosialisasi berupa penyuluhan kesehatan diharapkan dapat merubah sikap negatif. Sikap sesorang dapat dipengaruhi dari penerimaan informasi yang baik dengan pemberian penyuluhan kesehatan sehingga dapat berdampak pada penilaian seseorang terhadap suatu hal. Sikap individu atau kelompok dapat dipengaruhi dari pengetahuan, sikap seseorang dapat berubah dengan diperolehnya tambahan informasi tentang suatu informasi yang didapat. Pengaruh penyuluhan kesehatan memberikan dampak yang signifikan terhadap pengetahuan dan sikap masyarakat antara sebelum dan sesudah pemberian penyuluhan kesehatan.

\section{SIMPULAN DAN SARAN}

\section{Simpulan}

Tingkat pengetahuan masyarakat di wilayah Kerja Puskesmas Yosomulyo Kota Metro Lampung tentang kesehatan jiwa dalam kategori kurang dan sikap masyarakat kepada penderita gangguan jiwa sebelum diberikan pendidikan kesehatan dalam kategori sikap negatif. Setelah dilakukan penyuluhan kesehatan terdapat perubahan pengetahuan sebanyak 31.9\% dalam kategori pengetahuan baik. Sedangkan sikap terdapat peningkatan sebanyak $29.8 \%$ masyarakat berperilaku positif terhadap penderita gangguan jiwa.

Terdapat pengaruh pendidikan kesehatan terhadap perubahan tingkat pengetahuan dan sikap masyarakat pada gangguan jiwa di wilayah Kerja Puskesmas Yosomulyo Kota Metro Lampung yang ditandai kenaikan nilai rata-rata pengetahuan dan sikap antara sebelum dan sesudah pendidikan kesehatan.

\section{Saran}

Hasil penelitian ini diharapkan dapat dijadikan data awal untuk mengembangkan intervensi keperawatan jiwa bagi masyarakat untuk meningkatkan pengetahuan tentang gangguan jiwa sehingga tidak terjadi stigma negatif kepada penderita gangguan jiwa.

\section{DAFTAR PUSTAKA}

Arsyad A. (2006). Media Pembelajaran. Jakarta: Grasindo
Azwar, S. (2011). Sikap Manusia, Teori dan Pengukurannya. Yogyakarta : Pustaka Pelajar. 2013. Sikap Manusia, Teori dan Pengukurannya. Yogyakarta : Pustaka Pelajar.

Badan Penelitian \& Pengembangan Kesehatan Kementerian Kesehatan RI. (2013). Riset Kesehatan Dasar: http://depkes.go.id/downloads/ riskesdas2013/Hasil\%20Riskesdas\% 202013.pdf.

Daryanto, (2013). Inovasi Pembelajaran Efektif. Bandung: Yrma Widya.

Grasssi, M.C, dkk. 2014. Knowledge about Health Effect of Cigarette Smoking and Quitting among Italian University Student: The Importance of Teaching Nicotine Dependence and Treatment in Medical Curriculum. Hindawi Publishing Corporation BioMed Research International Volume 2014, Article ID 321657, diakses pada tanggal 18 Juni 2016.

Lacko-Evans, S, dkk. 2012. Public knowledge, attitudes and behavior regarding people with mental illness in England The British Journal of Psychiatry (2013) 202, s51-s57. doi: 10.1192/bjp.bp.112.112979, di akses pada tanggal 14 Juni 2016.

Nawawi, M (2013) Pengalaman Karies Dan Status Periodontal Pada Penderita Gangguan Jiwa di RSJ Mahoni Medan. Skripsi. Fakultas Kesehatan Gigi. Universitas Sumatera Utara

Nondyawati, K.A. 2015. Hubungan Pengetahuan dan sikap dengan motivasi keluarga dalam memberikan dukungan pada klien gangguan jiwa. Fakultas Ilmu Kesehatan Universitas Gresik, diakses pada 13 Juni 2016.

Notoatmodjo, Soekidjo. 2010. Promosi Kesehatan Masyarakat Teori dan Aplikasi. Rineka Cipta. Jakarta,

Pratomo, A.G.N. 2013. Pengaruh Pendidikan Kesehatan Terhadap Perubahan Tingkat Pengetahuan dan Sikap Masyarakat 
Pada Penderita Gangguan Jiwa di Desa Nguter Kabupaten Sukoharjo. http://eprints.ums.ac.id/26075/10/NASK AH_PUBLIKASI.pdf

Saam, Zulfan dan Wahyuni, Sri . (2012) Psikologi Keperawatan. Jakarta : Rajawali Pers.

Utami dan Marlyn, 2004. Gender Dan Keluarga : Konsep Realita. Jurnal. Psychiatric. http://www.uinalauddin.ac.id/download.pdf,. Widayatun. T.R. 2009.

Wawan dan Dewi, A. 2010. Pengetahuan, Sikap dan Perilaku Manusia. Yogyakarta: Numed.
Wiharjo (2014). Faktor yang mempengaruhi sikap masyarakat terhadap penderita skizofrenia. Diakses pada 4 Maret 2019

Yancen, P. Gangguan Jiwa itu Penyakit Medis, Bukan Aib atau Gangguan Mistis. http://www.radiopelitakasih.com/index.p hp/talk-show/item/496-gangguan-jiwaitu-penyakit-medis-bukan-aib-ataugangguan-mistis , 2015.

Yosep, Iyus., Sutini, Titin. (2014). Buku Ajar Keperawatan Jiwa (dan Advance mental healyh nursing). Bandung: Refika Aditama.

Yulianti .(2016). Hubungan antara tingkat penyuluhan dengan sikap masyarakat terhadap pasien gangguan jiwa. Diakses pada 3 Maret 2019 
Jurnal Keperawatan Jiwa Volume 7 No 1 Hal 87 - 94, Mei 2019

FIKKes Universitas Muhammadiyah Semarang bekerjasama dengan PPNI Jawa Tengah 